\title{
REVIEW
}

\section{Properties and Function of Nephrocalcin: Mechanism of Kidney Stone Inhibition or Promotion}

\author{
Yasushi Nakagawa \\ Nephrology Program, and Biochemistry and Molecular Biology, University of Chicago, Chicago, IL, USA
}

(Received for publication on June 18, 1996)

\begin{abstract}
Nephrocalcin (NC), an acidic glycoprotein with molecular weight 14,000 , is present in urine and prevents kidney stone formation. Histoimmunochemical staining shows that NC is localized in the proximal tubles in kidneys. Isolated NC from mammalian urine, revealed at least 4 isoforms of $\mathrm{NC}$ (we call these isoforms NC-A, NC-B, NC-C, and NC-D in the order of elution) during DEAE cellulose column chromatography with a linear gradient of $\mathrm{NaCl}$ elution step. Non-stone forming people excrete more $\mathrm{NC}$ - $\mathrm{A}$ and NC-B isoforms in urine; however, more NC-C and NC-D isoforms were found in stone formers' urine. When the organic matrix was extracted from surgically removed calcium oxalate kidney stones, we found greater quantities of NC-C and NC-D isoforms than those of NC-A and NC-B isoforms. Amino acid compositions and carbohydrate contents of these 4 isoforms were similar with the exception of the gammacarboxyglutamic acid (GLA) residues. Only the NC-A and NC-B isoforms contained residues of GLA. There were more phosphate residues present in NC-C and NC-D than in NC-A and NC-B. Upon removal of phosphate residues by alkaline phosphatase, $\mathrm{NC}-\mathrm{C}$ eluted at the same salt concentration as NC-A eluted. This indicates that the backbone protein could be similar, but the NC-C isoform is modified by excess phosphate residues. Surface tension measurements using a Lauda film balance indicated that NC-A and -B were strongly amphiphilic while NC-C and -D were less amphiphilic. NC-A has an elongated shape, and occupies a smaller area per molecule; whereas NC-C is a bulky molecule. Using NC-A as a model of a "good" inhibitor and NC-C as a model of a "poor" inhibitor, both bound with 4 atoms of $\mathrm{Ca}^{2+}$ per molecule as investigated by equilibrium dialysis method, ${ }^{31} \mathrm{P}-\mathrm{NMR}$, and electron spin resonance spectrometry. Isoforms $\mathrm{A}$ and $\mathrm{B}$ changed their conformation upon $\mathrm{Ca}^{2+}$ binding, but $\mathrm{C}$ and $\mathrm{D}$ did not change their conformation. All these observations suggest that isoforms $A$ and $B$ are strong inhibitors of calcium oxalate monohydrate (COM) crystal growth and aggregation. However, isoforms $C$ and $D$ act as promotors for $\mathrm{COM}$ crystal growth-kidney stone formation. Measuring the amount of $\mathrm{NC}$ in urine from renal cell carcinoma patients and from NC isolated from a supernatant of a primary renal cell carcinoma cells demonstrated the amount of $\mathrm{NC}$ increased with disease progression. (Keio J Med 46 (1): 1-9, March 1997)
\end{abstract}

Key words: nephrocalcin, kidney stone inhibitor, urolithiasis, kidney stone

\section{Introduction}

Kidney stone disease has been well documented in medical history; however, it has been not given a great deal of attention due to fact that it is not a life-threatening disease and affects a minority of the population. Recently this disease has been the focus of special attention, and meetings and symposiums have been organized in America, Europe, and Japan.

Many hypotheses have been proposed for the formation of calcium kidney stones; kidney stone promoters ${ }^{1}$ and inhibitors ${ }^{2}$ which are inorganic and organic compounds. Molecular weights of these promoters and inhibitors range from less than 100 to over $100 \mathrm{kd}$.

中川 泰

Presented at the 967th Meeting of The Keio Mecial Society in Tokyo, May 28, 1996.

Reprint requests to: Dr Yasushi Nakagawa, Nephrology Program, and Biochemistry and Molecular Biology, University of Chicago, 5841 S. Maryland Ave, Chicago, IL 60637, USA 
Known biological minerals, such as bone, ${ }^{3}$ teeth, ${ }^{4}$ shells, ${ }^{5}$ and kidney stones ${ }^{6,7}$ contain an organic matrix. Many of proteins reported to make up the matrix include: Albumin, ${ }^{8}$ alpha 1-antitrypsin, ${ }^{9}$ chondroitin sulfate, ${ }^{10}$ crystal matrix protein, ${ }^{11}$ prothrombin-like protein, ${ }^{12}$ RNA-fragments. ${ }^{13}$ alpha 2-microglobulin (or alpha-1microglobulin), ${ }^{1+}$ Apolipoprotein $\mathrm{A},{ }^{15}$ Tamm-Horsfall glycoprotein, ${ }^{16}$ uropontin. ${ }^{17}$ These compounds have been reported to be present in kidney stones, but their function as an inhibitor or a promoter has remained unknown.

We isolated an acidic glycoprotein with a mol. wt. of $14 \mathrm{kd}$ in a monomeric form (nephrocalcin, NC) from urine and kidney tissues of 9 mammalian species ${ }^{18}$ and from surgically removed kidney stones. ${ }^{7}$ These isolated NCs separated into 4 isoforms. ${ }^{19}$ I will discuss the chemical and physicochemical properties of these isoforms and describe their potential functions.

Immunohistochemical staining showed that NC is localized in the proximal tubules of the kidneys. This was further proven by the identification of $\mathrm{NC}$ from tissue culture medium of primary proximal tubule cells.

Over $85 \%$ of renal carcinoma develops in proximal tubule cells. ${ }^{20}$ Therefore, we quantitatively analyzed NC levels in the urines of renal cell carcinoma patients by ELISA method and found those levels to be elevated. After renal cell carcinoma patients had a nephrectomy, NC levels were reduced.

\section{Isolation of Nephrocalcin}

The first step of isolation was anion exchange column chromatography using DEAE cellulose. In most samples calcium oxalate $(\mathrm{CaOx})$ inhibitory activity appeared in 4 ionic strength regions, A (12-15 mS), B (16-22 mS), $\mathrm{C}(23-28 \mathrm{mS})$, and $\mathrm{D}(29-40 \mathrm{mS})$. Figure 1 shows typical elution patterns of DEAE cellulose column chromatography of a single urine samples from normal male and female, and stone former male and female. We noticed that normal urine contains more $\mathrm{A}$ and $\mathrm{B}$ than $\mathrm{C}$ and $\mathrm{D}$. However, kidney stone forming patients excretes more $\mathrm{C}$ and $\mathrm{D}$ than $\mathrm{A}$ and $\mathrm{B}$ in urine (Fig 2). The same relationship was observed in $\mathrm{CaOx}$ kidney stone extracts.

\section{Chemical Compositions of NC Isoforms}

Amino acid analyses of the isomers are summarized in Table 1. The amino acid compositions are similar but gamma-carboxyglutamic acid (GLA) contents are different: Isoform A obtained from normal urine contains 3 residues, $\mathrm{B}$ and $\mathrm{C}$ contain 2 residues, and $\mathrm{D}$ does not contain any GLA residues. In contrast, all 4 isoforms obtained from kidney stone patients contained no GLA residue.

Carbohydrate contents are shown in Table 2. No significant differences were observed among normal and

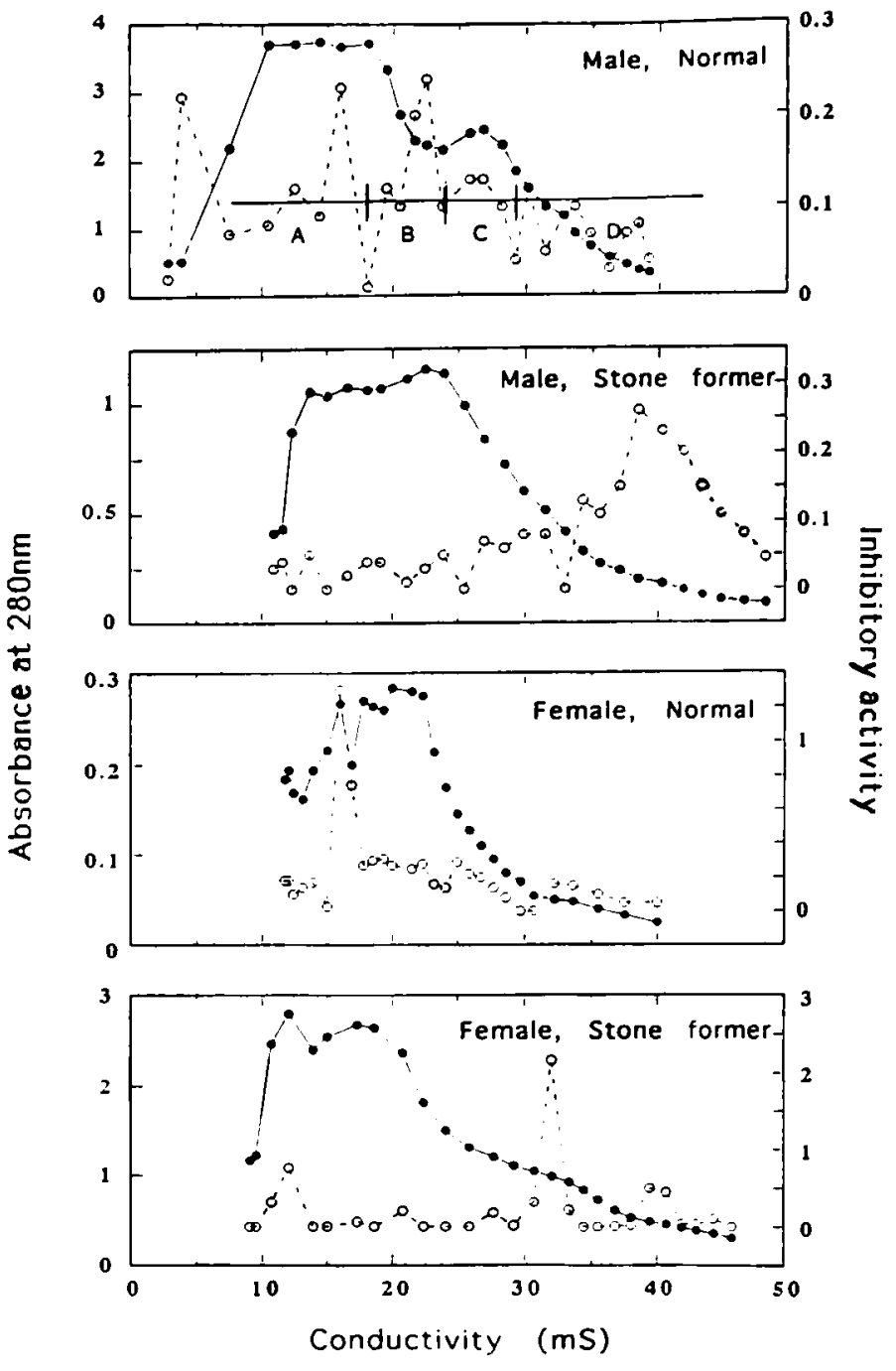

Fig 1 Elution patterns of protein and nephrocalcin from DEAE cellulose column using linear $\mathrm{NaCl}$ gradient from 0.1 to $0.5 \mathrm{M}$ in $0.05 \mathrm{M}$ Tris-HCl, pH 7.3 as a solvent. Protein $(\bullet-\bullet)$ and Inhibitor $(0--\circ)$. Typical elution pattern is demonstrated using a single urine sample obtaincd from normal malc and female, and stone forming male and femalc patients.

stone former isoforms.

\section{Physicochemical Properties}

Dissociation constants against calcium oxalate monohydrate crystals were determined by plotting Langmuir isotherm type plot. The results are shown in Fig 3. Normal isoform A shows a 10-fold stronger binding to $\mathrm{CaOx}$ molecule than stone formers' $\mathrm{C}$ isoform.

When surface tension of isoforms was measured using a Lauda film balance, normal isoforms, A, B, and C showed high collapse pressure; however, stone formers $\mathrm{NC}$ isomers, A, B, C, and D showed low collapse pressure (Fig 4). This indicates that normal NCs are amphiphylic but stone formers' NCs are less amphiphylic, 

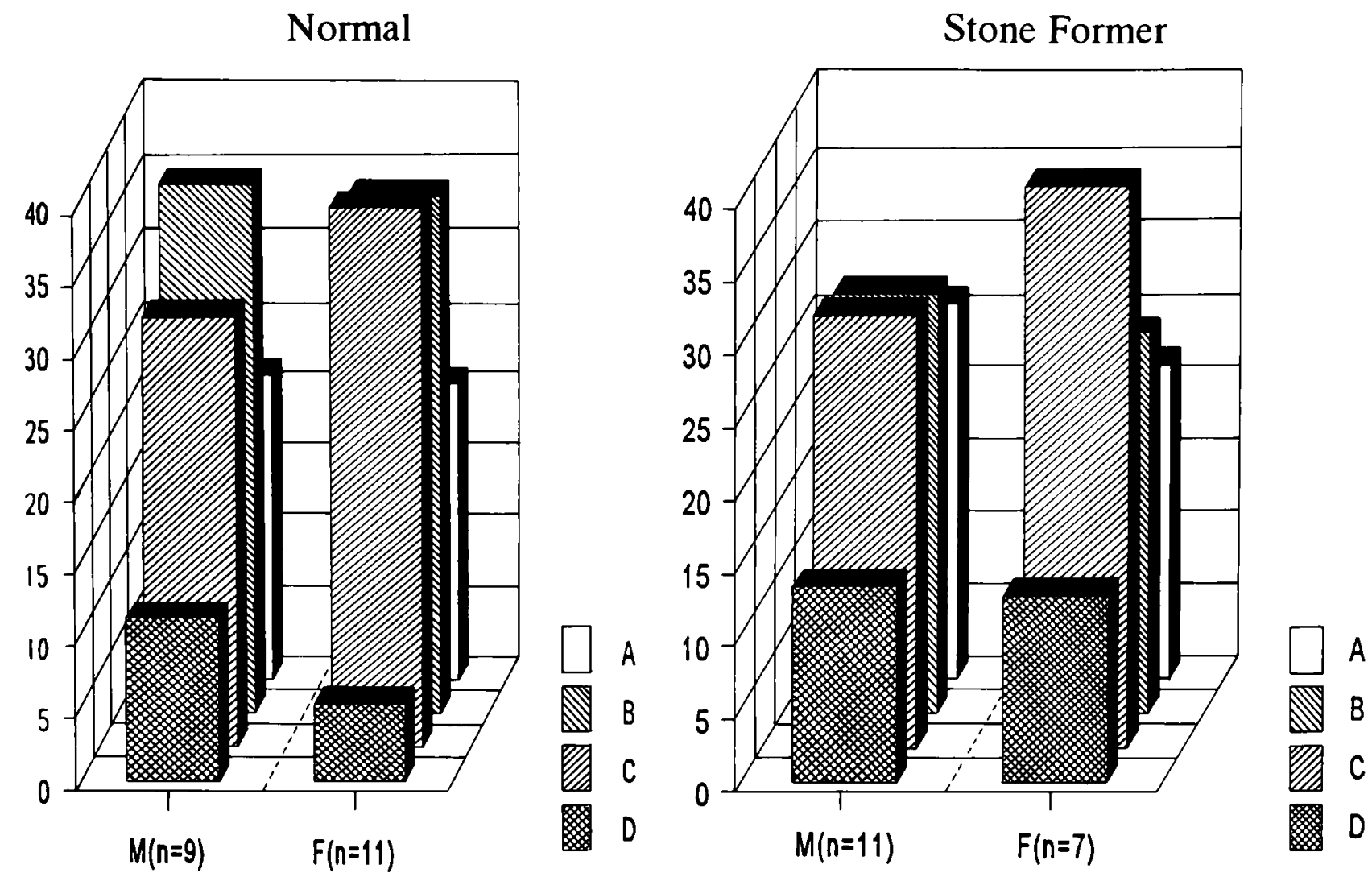

Fig 2 Distribution ratios of nephrocalcin isoforms in urine of normal subjects and stone formers.

Table 1 Amino Acid Compositions of 4 Nephrocalcin Isoforms Purificd from Normal (N) and Stonc Formers (P) Urine

\begin{tabular}{|c|c|c|c|c|c|c|c|c|}
\hline & \multicolumn{2}{|c|}{ A } & \multicolumn{2}{|c|}{ B } & \multicolumn{2}{|c|}{$\mathrm{C}$} & \multicolumn{2}{|c|}{$\mathrm{D}$} \\
\hline & $N$ & $\mathbf{P}$ & $N$ & $\mathbf{P}$ & $\mathrm{N}$ & $\mathbf{P}$ & $\mathbf{N}$ & $\mathrm{P}$ \\
\hline Lysinc & 2.5 & 1.6 & 2.4 & 1.7 & 2.8 & 2.3 & 2.0 & 2.0 \\
\hline Histidine & 2.0 & 1.4 & 1.0 & 2.0 & 1.8 & 2.4 & 2.5 & 2.5 \\
\hline Arginine & 2.4 & 2.2 & 1.6 & 2.6 & 2.8 & 2.4 & 2.3 & 2.3 \\
\hline Aspartic Acid & 12.9 & 14.2 & 13.2 & 11.8 & 11.4 & 12.1 & 11.2 & 11.2 \\
\hline Threoninc & 13.9 & 11.5 & 8.4 & 8.0 & 9.5 & 10.0 & 11.5 & 12.0 \\
\hline Scrinc & 9.8 & 9.8 & 10.6 & 8.8 & 10.0 & 11.0 & 11.4 & 11.4 \\
\hline Glutamic Acid & 13.2 & 13.1 & 13.4 & 14.4 & 12.6 & 13.3 & 12.2 & 12.2 \\
\hline Prolinc & 8.8 & 7.5 & 6.7 & 7.2 & 7.5 & 9.0 & 7.2 & 7.2 \\
\hline Glycinc & 9.5 & 10.5 & 9.2 & 11.8 & 10.0 & 12.2 & 11.0 & 11.0 \\
\hline Alanine & 9.2 & 7.9 & 9.4 & 6.4 & 9.0 & 9.7 & 9.7 & 8.7 \\
\hline 1/2 Cystinc & 2.11 & 1.8 & 1.9 & 1.3 & 1.6 & 1.7 & 2.4 & 2.4 \\
\hline Valine & 7.2 & 7.5 & 7.6 & 6.4 & 6.8 & 7.8 & 8.9 & 7.9 \\
\hline Mcthioninc & 1.4 & 0.6 & 0.7 & 0.5 & 0.6 & 0.8 & 1.3 & 1.3 \\
\hline Isolcucinc & 3.0 & 3.3 & 2.0 & 2.2 & 2.5 & 3.1 & 3.0 & 3.0 \\
\hline Lcucine & 9.9 & 7.5 & 7.5 & 5.2 & 7.6 & 9.3 & 7.7 & 6.7 \\
\hline Tyrosine & 1.7 & 1.2 & 1.0 & 1.0 & 1.8 & 2.8 & 2.7 & 3.5 \\
\hline Phenylalanine & 4.0 & 3.4 & 2.6 & 2.8 & 2.4 & 2.5 & 3.5 & 3.5 \\
\hline Tryptophan & 1.4 & ND & 1.1 & ND & 0.9 & ND & 1.2 & ND \\
\hline$\gamma$-Carboxyglutamic Acid & 3.4 & 0 & 2.1 & 0 & 2.0 & 0 & 0 & 0 \\
\hline
\end{tabular}


Table 2 Carbohydrate Compositions of 4 Nephrocalcin Isoforms

\begin{tabular}{|c|c|c|c|c|c|c|c|c|}
\hline \multirow[b]{2}{*}{ Carbohydrate } & \multicolumn{2}{|c|}{ A } & \multicolumn{2}{|c|}{ B } & \multicolumn{2}{|c|}{$\mathrm{C}$} & \multicolumn{2}{|c|}{ D } \\
\hline & $\mathbf{N}$ & $\mathbf{P}$ & $\mathbf{N}$ & $\mathbf{P}$ & $\mathbf{N}$ & $\mathbf{P}$ & $\mathbf{N}$ & $\mathbf{P}$ \\
\hline Fucose & 0.3 & 0.3 & 0.3 & 0.1 & 0.3 & 0.1 & 0.1 & 0.4 \\
\hline Galactose & 3.2 & 3.2 & 2.5 & 3.7 & 2.2 & 1.3 & 3.7 & 0.7 \\
\hline Mannose & 0.8 & 0.9 & 1.2 & 0.2 & 1.1 & 0.4 & 0.2 & 0.6 \\
\hline Glucose & 0.6 & 0.6 & 1.2 & 0.3 & 0.1 & 0.2 & 0.3 & 0.9 \\
\hline Galactosamine & 0.8 & 0.8 & 1.5 & 2.7 & 0.8 & 1.4 & 2.7 & 1.2 \\
\hline Glucosamine & 0.4 & 0.4 & 1.0 & 0.4 & 0.8 & 0.1 & 0.4 & 1.2 \\
\hline$N$-Acetylneuraminic Acid & + & + & + & + & + & + & + & + \\
\hline Total & 6.1 & 6.2 & 10.3 & 7.4 & 5.3 & 3.5 & 7.7 & 5.0 \\
\hline
\end{tabular}

A-D refer to fractions eluted from DEAE-cellulose; see Methods and legend to Table $1 . \mathbf{N}$; normal subjects. P; patients. All values are weight percentage.

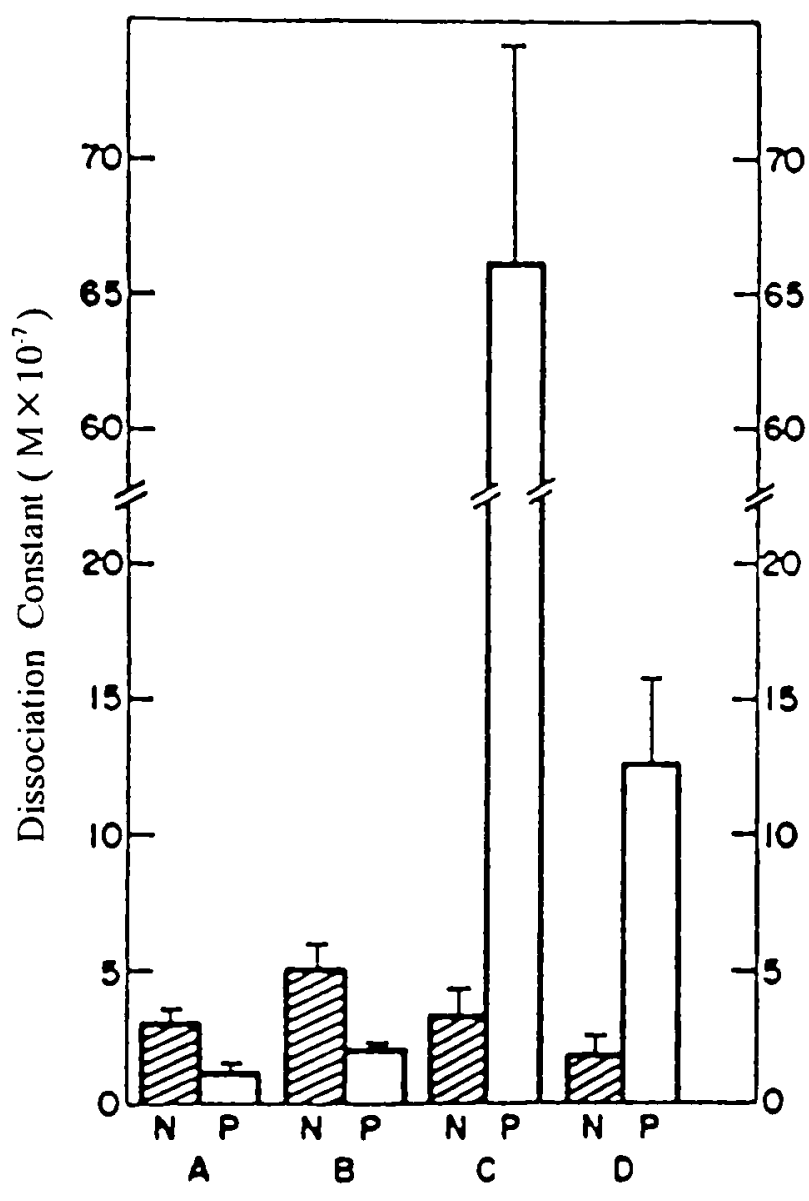

Fig 3 Langmuir adsorption coefficients. Values \pm SEM for normals (N. crosshatch) and patients (P. open bars) for $\mathrm{A}-\mathrm{D}$ isoforms.
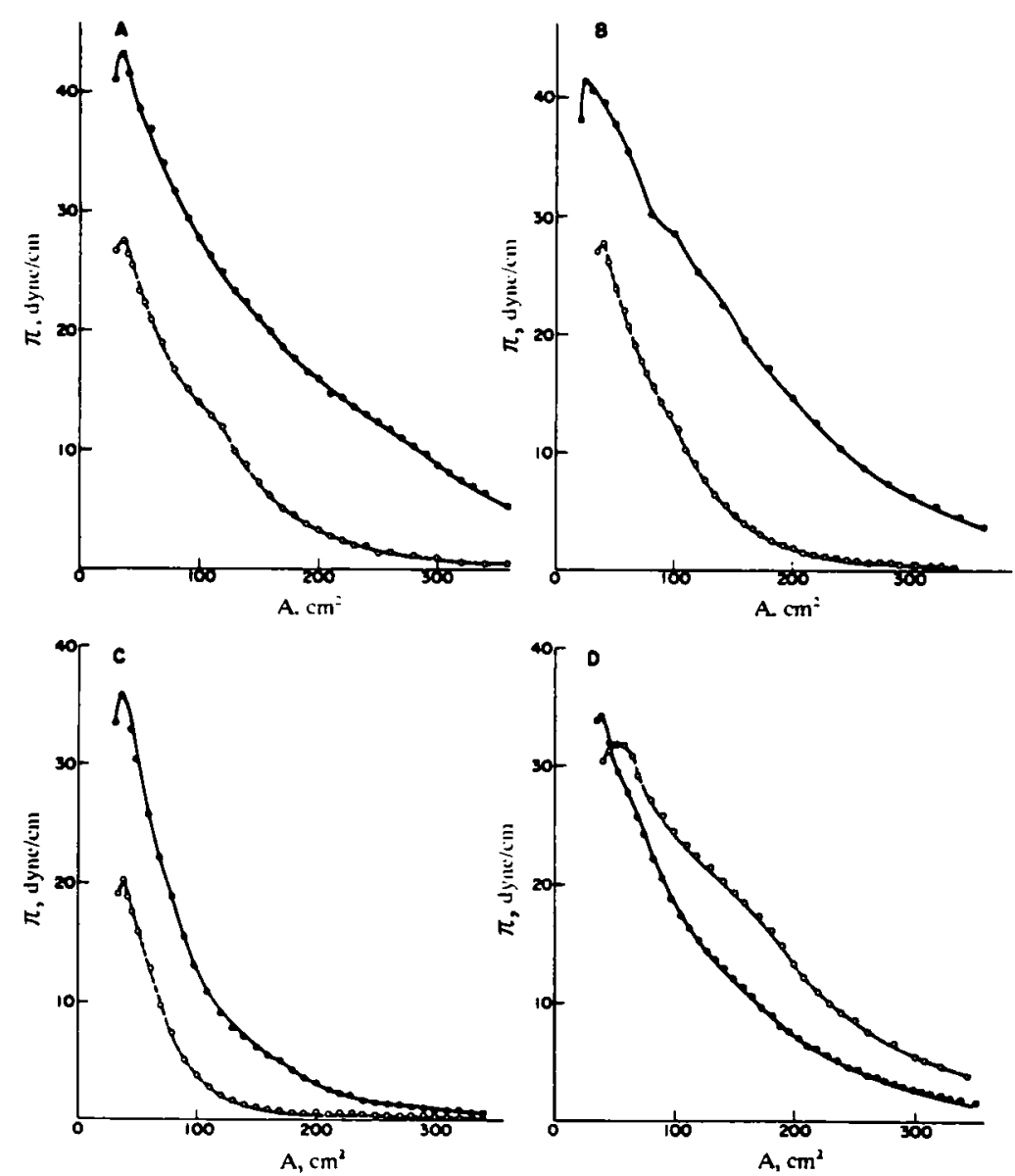

Fig 4 Force area curves for A - D isoforms (Figs 4 A - D, respectively) from normals $(\bullet)$ and patients $(O)$. Surface films of $135 \mu \mathrm{g}$ protein were compressed and expanded between 600 and $20 \mathrm{~cm}^{2}$ at $2.2 \mathrm{~cm}^{2} / \mathrm{sec}$. Collapse pressures of normal A-C exceeded corresponding values for patient materials: 33.2 vs $27.8,41.4$ vs 17.6 , and 36 vs 20.4 : values for $D$ were nearly the same: 34.2 vs 32 . 
that is normal NCs are less water soluble than stone formers NCs.

${ }^{32} \mathrm{P}-\mathrm{NMR}$ spectrometer indicates that phosphate residues are present as phosphoserine, and a chemical shift indicates $4 \mathrm{Ca}^{2+}$ atoms saturate one molecule of $\mathrm{NC}$ (Fig 5).

Circular dichroism (CD) spectrometer was used for investigation of conformational changes of these NCs by titrated with $\mathrm{Ca}^{2+}$. Isomer $\mathrm{A}$ changed its conformation when titrating with $\mathrm{Ca}^{2+}$, causing decreased alpha-helical structure and increased beta-sheet. Isomer $\mathrm{C}$, an example of stone former's inhibitor, did not change its conformation upon adding $\mathrm{Ca}^{2+}$ (Fig 6).

We used electron paramagnetic resonance spectroscopy (EPR) and electron nuclear double resonance spectroscopy (ENDOR) to investigate metal binding mode of these NCs. ${ }^{21}$ Since $\mathrm{Ca}^{2+}$ is spectroscopically silent, we used vanadyl ion $\left(\mathrm{VO}^{2+}\right)$. Figure 7 shows the EPR spectra of $\mathrm{VO}^{2+}$-NC-A complexes. An increase in signal amplitude was observed up to a $\mathrm{VO}^{2+}$-NC-A molar ratio of $4: 1$. The $-3 / 2$ perpendicular resonance feature was plotted as a function of the $\mathrm{VO}^{2+}: \mathrm{NC}-\mathrm{A}$ ratio. The signal intensity increased up to a $\mathrm{VO}^{2+}: \mathrm{NC}-\mathrm{A}$ ratio of $4: 1$, and then remained constant. This indicates that the stoichiometry of $\mathrm{VO}^{2+}$-binding to NC-A is $4: 1$ (Fig 8). A similar conclusion was observed by ${ }^{32} \mathrm{P}-\mathrm{NMR}$ and equi-

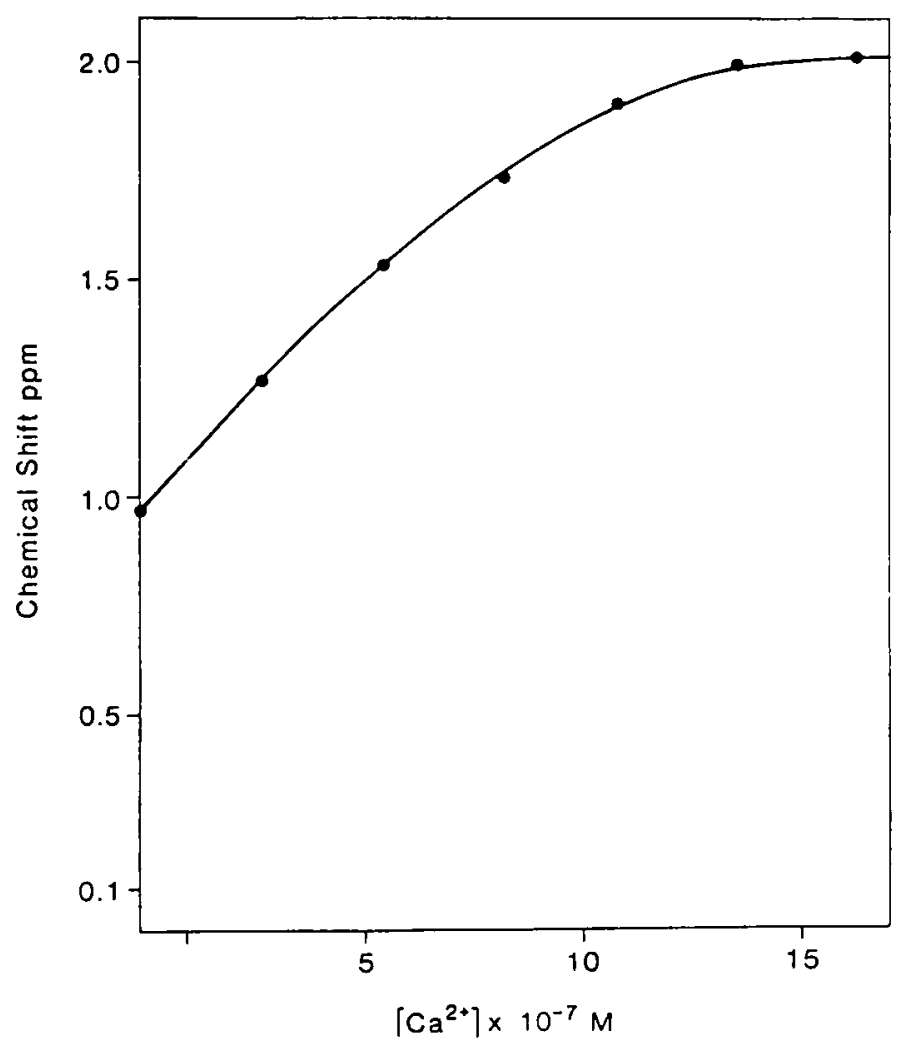

Fig 5 Effects of $\mathrm{Ca}^{2+}$ concentration on the ${ }^{31} \mathrm{P}$ NMR chemical shift. librium dialysis of $\mathrm{NC}-\mathrm{A}$ with ${ }^{45} \mathrm{Ca}$. When $\mathrm{VO}^{2+}$ was added to $\mathrm{Ca}^{2+}$ saturated NC-A, no $\mathrm{VO}^{2+}$ bound to the protein. Thus we concluded that $\mathrm{Ca}^{2+}$ and $\mathrm{VO}^{2+}$ compete for the same calcium binding sites. We also analyzed EPR linewidths, and found that the linewidth of solvated vanadyl ion decreased $6 \mathrm{G}$ (Gauss), but $\mathrm{VO}^{2+}-\mathrm{NC}-\mathrm{A}$ complexes remained unchanged. This indicates that in the $\mathrm{VO}^{2+}-\mathrm{NC}-\mathrm{A}$ complex no solvent molecule is directly coordinated to the $\mathrm{VO}^{2+}$ ion. A model of a poor inhibitor, $\mathrm{NC}-\mathrm{C}$, was used in the same manner as described above for NC-A. The binding of $\mathrm{VO}^{2+}$ to $\mathrm{NC}-\mathrm{C}$ was competitive with $\mathrm{Ca}^{2+}$, and metal protein binding stoichiometry was $4: 1$. Contrary to NC-A, the decrease in linewidth of the $-3 / 2$ perpendicular EPR upon introduction of $\mathrm{D}_{2} \mathrm{O}$ was $2.37 \mathrm{G}$. This suggests that in the $\mathrm{VO}^{2+}-\mathrm{NC}-\mathrm{C}$ complex at least 1 or 2 water molecules are directly involved with the $\mathrm{VO}^{2+}$ ion as an equatorial ligand.

\section{Localization of $\mathrm{NC}$ in Kidney Tissues}

Polyclonal antibody against human NC was raised in rabbits using Freund's adjuvant, and boosted twice before
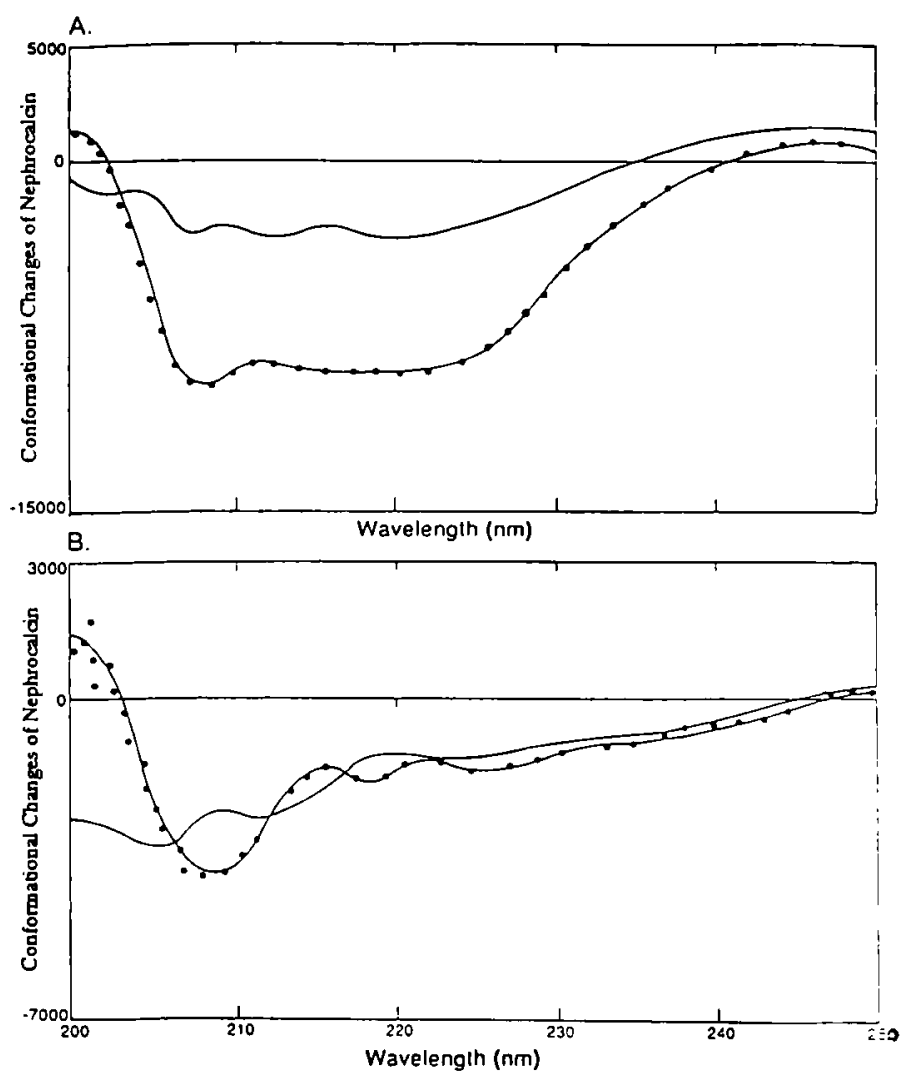

Fig 6 Circular dichroic spectra of nephrocalcin in the absence and in the presence of $\mathrm{Ca}^{2+}$. A (upper panel) shows NC-A: Frec NC-A $(\cdot-\cdot-\cdot)$, and $4 \mathrm{Ca}^{2+}$ atoms bound per $1 \mathrm{Na}-\mathrm{A}$ moleculc $(-)$. B (lower panel) shows NC-C: The same as above, $\mathrm{Ca}^{2+}$ free $(\cdot-\cdot-\cdot)$ and $\mathrm{Ca}^{2+}$ bound $(-)$. 


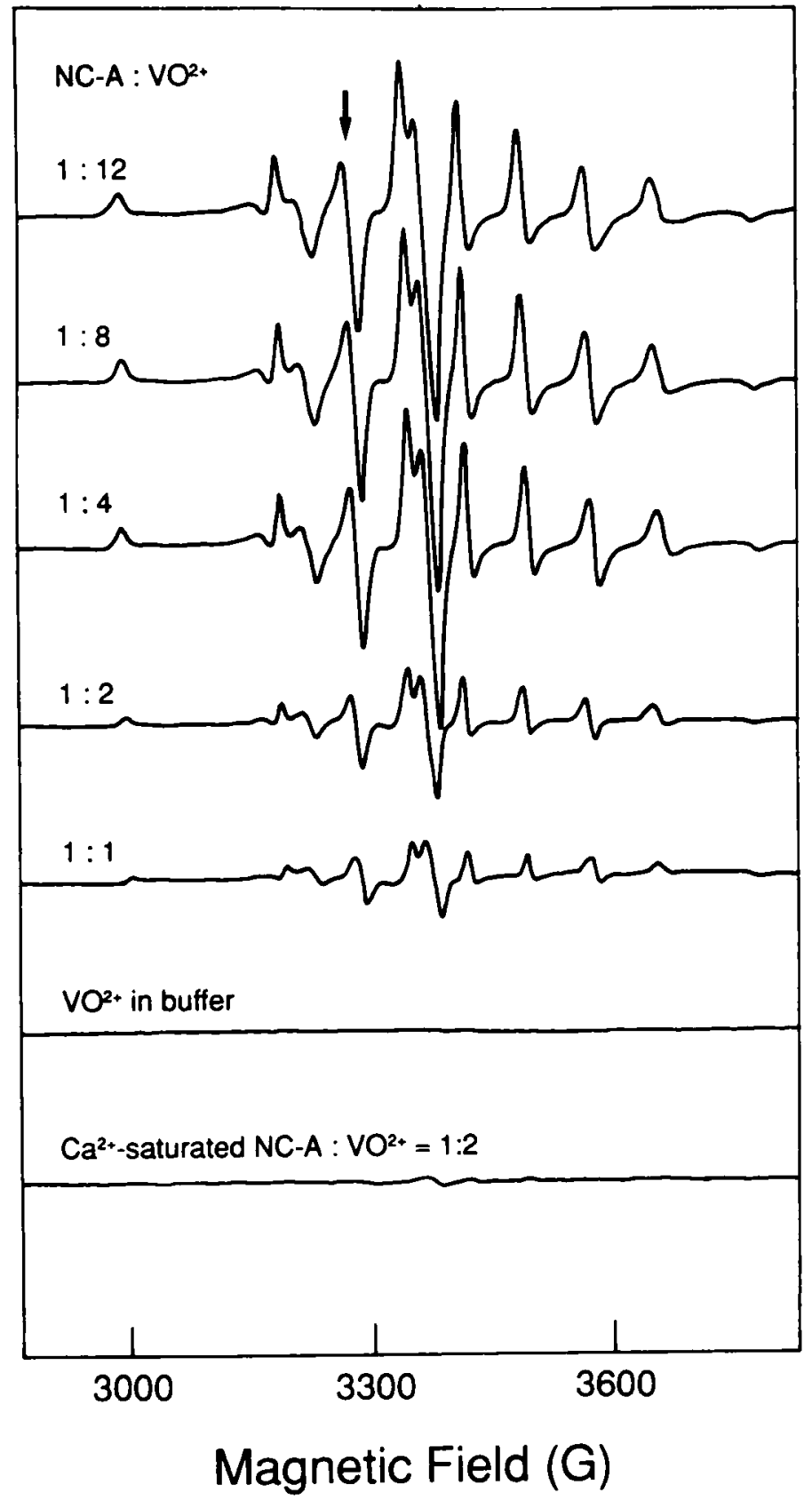

Fig 7 First derivative EPR spectra of $\mathrm{VO}^{2+}-\mathrm{NC}$ complexes in frozen aqueous solution. The solutions were buffered to $\mathrm{pH} 5.8$ with $0.03 \mathrm{M}$ Pipes. The spectra were recorded under identical spectrometer settings with different $\mathrm{NC}: \mathrm{VO}^{2+}$ molar ratios as indicated. The final $\mathrm{NC}$ concentration was $1 \mathrm{mM}$.

blood collection. The titer was 1:15,000. Using this antibody, slice of kidney tissue were double stained immunohistochemically using Tamm-Horsfall glycoprotein as a marker. Darker staining patterns were observed along proximal tubules.

Proximal tubules were isolated from female mice kidneys by density gradient centrifugation using $45 \%$ Percoll, and cultured to confluency in serum-free culture

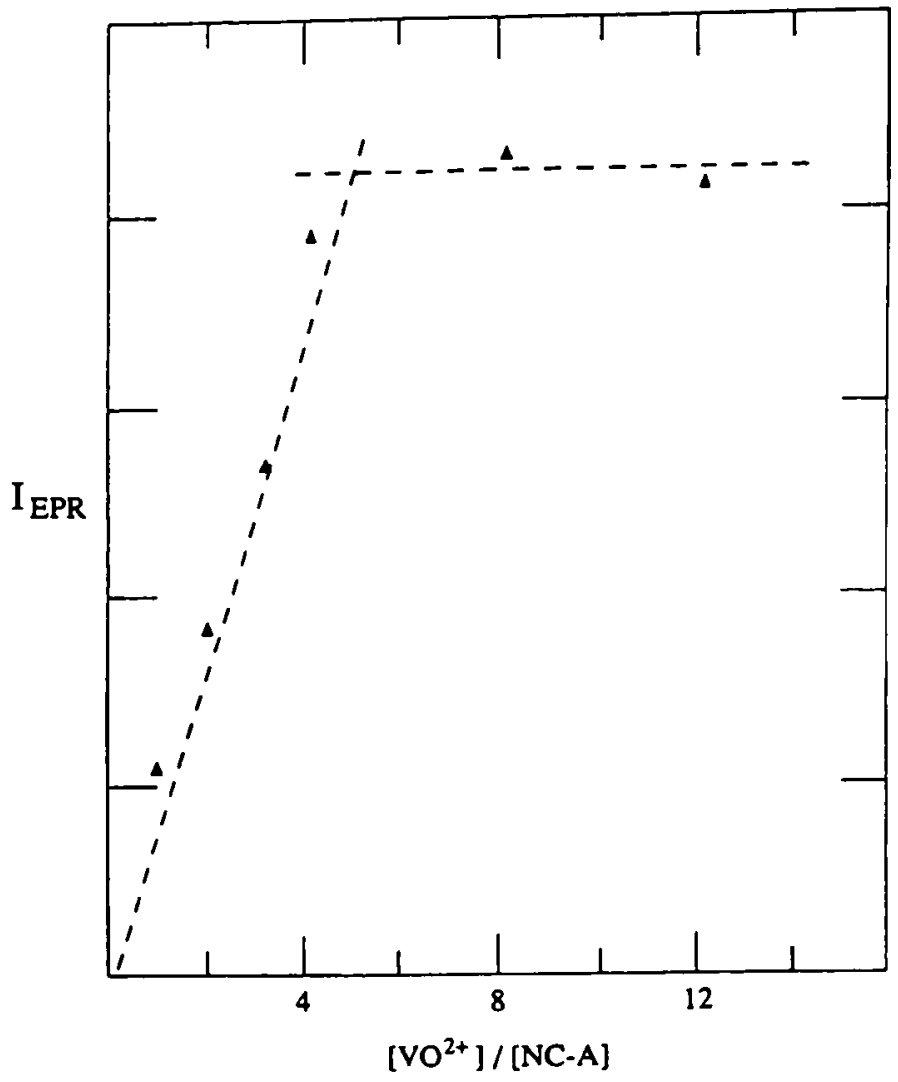

Fig 8 EPR spectrometric titration of the $\mathrm{VO}^{1+}$ ion complexed to $\mathrm{NC}$ $A$ isoform. The EPR signal intensities of $-3 / 2$ perpendicular line of $\mathrm{VO}^{2+}$ are plotted as a function of $\mathrm{VO}^{2+}: \mathrm{NC}-\mathrm{A}$ ratio.

medium for 7-9 days. The tissue culture media was collected every 3 days and stored for isolation of NC. Purified NC, $636 \mu \mathrm{g}$, was obtained from $1 \mathrm{~g}$ of protein in the tissue culture media. Although carbohydrate contents were higher than those found in human and rat NCs, amino acid compositions and dissociation constants were very similar to NCs isolated from human and other vertebrates (Table 3).

\section{Nephrocalcin in Human Renal Carcinoma Cells}

Since $85 \%$ of renal cell carcinoma develope in proximal tubule cells, renal cell carcinoma kidney tissue cells were immuno-histochemically stained. The amount of NC in urine of renal cell carcinoma patients ( 9 men and 10 women, age 40 to 71 years old, mean age 55 years) was increased as shown in Fig 9. Tumors were of the clear cell and granular cell varities, moderately differentiated and of pathological stage $T_{2} N_{0} M_{0}$ with exception of 4 patients with stage $T_{3}$ disease but without local or distant metastases (Table 4). Urine was collected the day before and 5 to 90 days (mean 14 days) after radical nephrectomy. Four healthy adult biologically related kidney donors submitted a urine sample 1 day before and 5 days after 
Table 3 Amino Acid Compositions of Nephrocalcins Isolated from Proximal Tubule Cell Cultured Medium

\begin{tabular}{|c|c|c|c|c|c|c|c|}
\hline \multirow{2}{*}{ Amino Acid } & \multicolumn{4}{|c|}{ DEAE Fraction, wt $\%$} & \multirow{2}{*}{$\begin{array}{l}\text { Human } \\
\text { Urine } \\
\text { NC (12) }\end{array}$} & \multicolumn{2}{|c|}{ Rat NC (11) } \\
\hline & $A$ & $B$ & $C$ & $D$ & & Kidney & Urine \\
\hline Lysine & 3.6 & 4.3 & 4.5 & 5.7 & 4 & 3 & 4 \\
\hline Histidine & 3.5 & 2.1 & 3.1 & 4.0 & 2 & 2 & 2 \\
\hline Arginine & 4.9 & 3.9 & 2.6 & 3.2 & 5 & 3 & 4 \\
\hline Aspartic Acid & 12.3 & 12.1 & 12.1 & 11.8 & 12 & 12 & 12 \\
\hline Threonine & 7.1 & 10.8 & 5.6 & 6.5 & 10 & 9 & 8 \\
\hline Serine & 8.1 & 8.1 & 9.0 & 7.6 & 11 & 12 & 13 \\
\hline Glutamic Acid & 15.4 & 13.0 & 12.0 & 12.6 & 13 & 16 & 18 \\
\hline Proline & 8.1 & 8.5 & 4.7 & 6.7 & 6 & 7 & 6 \\
\hline Glycine & 15.4 & 12.8 & 9.7 & 11.9 & 12 & 9 & 9 \\
\hline Alanine & 14.6 & 13.1 & 14.0 & 11.0 & 8 & 6 & 7 \\
\hline Valine & 7.9 & 6.6 & 5.8 & 6.8 & 7 & 7 & 7 \\
\hline Isoleucine & 4.1 & 3.7 & 4.1 & 4.5 & 3 & 4 & 4 \\
\hline Leucine & 9.7 & 5.9 & 6.1 & 7.9 & 7 & 8 & 8 \\
\hline Tyrosine & 1.3 & 0.6 & 0.8 & 1.7 & 1 & 2 & 2 \\
\hline Phenylalanine & 3.4 & 2.4 & 3.6 & 4.5 & 3 & 4 & 3 \\
\hline$\gamma$-Glutamic Acid & 1.7 & 0.3 & 0.03 & 0 & 2 & 2 & 1 \\
\hline
\end{tabular}

Table 4 Status of 19 Patients with Renal Cell Car Inoma

\begin{tabular}{|c|c|c|c|c|c|c|}
\hline \multirow[b]{2}{*}{ Patient } & \multirow[b]{2}{*}{ Age/Sex } & \multirow[b]{2}{*}{ Stage } & \multirow[b]{2}{*}{ Grade } & \multirow[b]{2}{*}{$\begin{array}{c}\text { Cell Type } \\
\text { (Clear, Granular) }\end{array}$} & \multicolumn{2}{|c|}{ ug NC/mg Creatinene } \\
\hline & & & & & pre-op & post-op \\
\hline & $58 \mathrm{~F}$ & & 2 & $\mathrm{Cl}$ & .077 & .108 \\
\hline & $41 \mathrm{~F}$ & $\mathrm{~T}_{3 \mathrm{a}} \mathbf{N}_{\mathrm{o}} \mathbf{M}_{\mathrm{o}}$ & 2 & Gr & .464 & .243 \\
\hline & $45 \mathrm{~F}$ & $\mathrm{~T}_{2} \mathrm{~N}_{\mathrm{o}} \mathrm{M}_{\mathrm{o}}$ & 3 & Gr & 1.432 & .255 \\
\hline & $68 \mathrm{~F}$ & $\mathrm{~T}_{3 \mathrm{~b}} \mathbf{N}_{\mathrm{o}} \mathrm{M}_{\mathrm{o}}$ & 1 & $\mathrm{Cl}$ & .158 & .031 \\
\hline & $49 \mathrm{~F}$ & $\mathrm{~T}_{2} \mathbf{N}_{\mathbf{x}} \mathbf{M}_{\mathrm{o}}$ & 2 & $\mathrm{Cl}$ & .258 & .187 \\
\hline & $62 \mathrm{M}$ & $T_{3 b} N_{x} M_{o}$ & 2 & $\mathrm{Cl}$ & .153 & .176 \\
\hline & $66 \mathrm{M}$ & $\mathbf{T}_{2} \mathrm{~N}_{\mathrm{x}} \mathrm{M}_{\mathrm{v}}$ & 2 & Gr & .065 & .013 \\
\hline & $42 \mathrm{~F}$ & $T_{2} N_{o} M_{0}$ & 2 & $\mathrm{Cl}$ & .068 & .064 \\
\hline & $40 \mathrm{M}$ & $\mathrm{T}_{2} \mathrm{~N}_{\mathrm{x}} \mathrm{M}_{\mathrm{o}}$ & 2 & $\mathrm{Cl}$ & .066 & .030 \\
\hline & $67 \mathrm{~F}$ & $\mathrm{~T}_{2} \mathrm{~N}_{\mathrm{o}} \mathrm{M}_{\mathrm{o}}$ & 2 & Gr & .012 & .079 \\
\hline & $65 \mathrm{M}$ & $\mathrm{T}_{2} \mathrm{~N}_{\mathrm{x}} \mathrm{M}_{\mathrm{o}}$ & 1 & $\mathrm{Cl}$ & .030 & .030 \\
\hline & $61 \mathrm{M}$ & $\mathbf{T}_{2} \mathbf{N}_{0} \mathbf{M}_{0}$ & 2 & Gr & .060 & .037 \\
\hline & $63 \mathrm{M}$ & $\mathrm{T}_{2} \mathrm{~N}_{\mathrm{x}} \mathrm{M}_{\mathrm{o}}$ & 2 & $\mathrm{Cl}$ & .049 & .039 \\
\hline & $70 \mathrm{~F}$ & $\mathrm{~T}_{2} \mathrm{~N}_{\mathrm{o}} \mathrm{M}_{\mathrm{o}}$ & 1 & $\mathrm{Cl}$ & .454 & .320 \\
\hline & $60 \mathrm{M}$ & $\mathbf{T}_{2} \mathbf{N}_{\mathrm{o}} \mathrm{M}_{\mathrm{o}}$ & 2 & $\mathrm{Cl}$ & .086 & .038 \\
\hline & $41 \mathrm{M}$ & $\mathrm{T}_{1} \mathrm{~N}_{\mathrm{o}} \mathrm{M}_{\mathrm{o}}$ & 2 & $\mathrm{Gr}$ & .026 & .118 \\
\hline & $43 \mathrm{M}$ & $\mathrm{T}_{3} \mathrm{~N}_{\mathrm{x}} \mathrm{M}_{\mathrm{o}}$ & 2 & $\mathrm{Cl}$ & .125 & .173 . \\
\hline & $62 \mathrm{~F}$ & $\mathrm{~T}_{2} \mathrm{~N}_{\mathrm{x}} \mathrm{M}_{\mathrm{o}}$ & 1 & $\mathrm{Gr}$ & .681 & .372 \\
\hline & $71 \mathrm{~F}$ & $\begin{array}{l}T_{2} N_{0} M_{o} \\
T_{2} N_{0} M_{0}\end{array}$ & 2 & $\mathrm{Cl}$ & .288 & .082 \\
\hline
\end{tabular}

transplant nephroectomy to determine the effect of nontumor nephrectomy on excretion of nephrocalcin. The mean level of $\mathrm{NC}$ in 19 renal cell carcinoma patients was $0.241 \pm 0.341 \mu \mathrm{g}$ per $\mathrm{mg}$ creatinine compared to $0.022+0.012 \mu \mathrm{g}$ per $\mathrm{mg}$ creatinine for normal controls $(\mathrm{p}=0.0112)$. Mean NC after tumor nephrectomy was $(0.097 \pm 0.087) \mu \mathrm{g}$ per $\mathrm{mg}$ creatinine. Chemical and physicochemical properties of purified NC isolated from urine of these patients were similar to those of previously described NCs. 


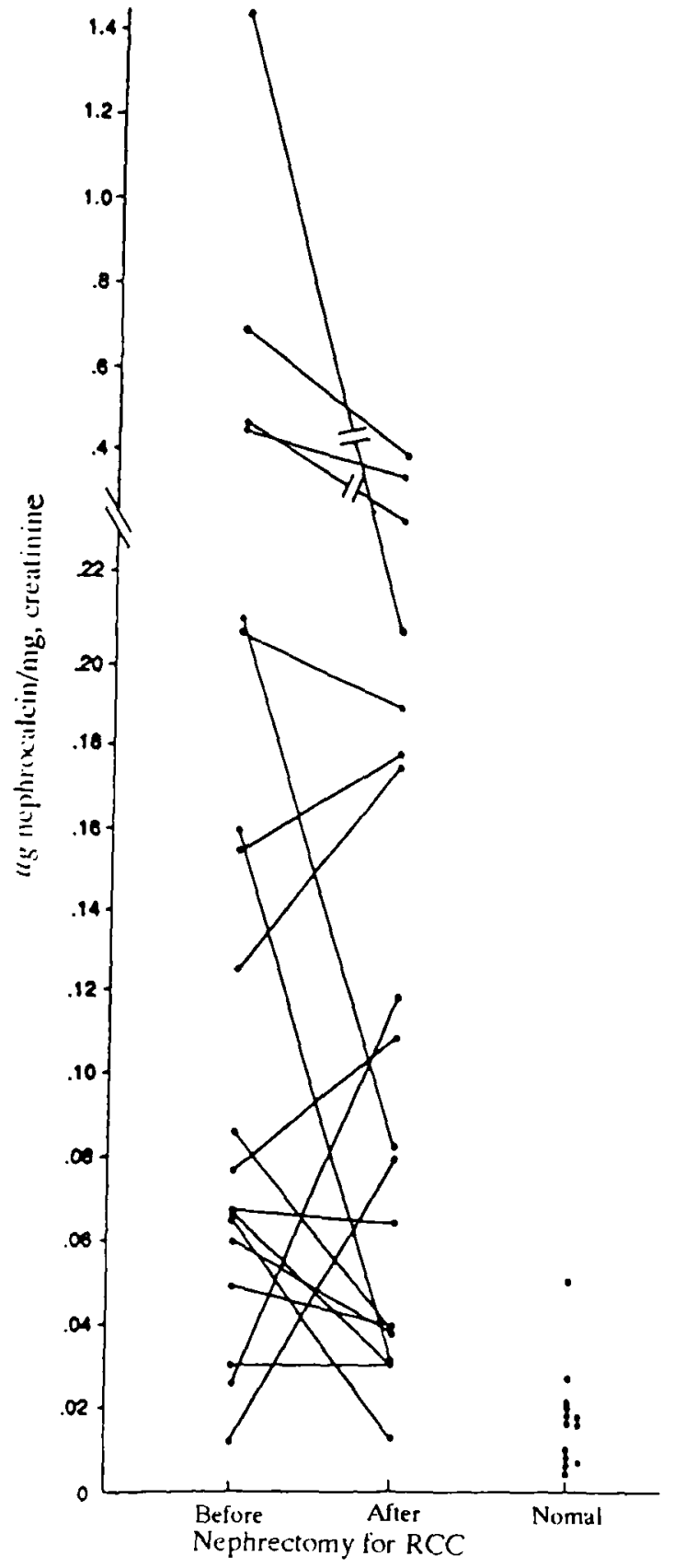

Fig 9 Changes of NC levels of 19 renal cell carcinoma patients before and after nephrectomy

\section{Discussion}

I have described chemical and physico-chemical properties between 4 isoforms of NC molecules. Good inhibitors, isoforms $\mathrm{A}$ and $\mathrm{B}$, have strong amphiphylicities, stronger binding capacities toward $\mathrm{CaOx}$, change conformation upon binding with $\mathrm{Ca}^{2+}$, and bind metal-proteins without the involvement of water molecules. In contrary, poor inhibitors, isoforms $\mathrm{C}$ and $\mathrm{D}$, are less amphyphilic, have no conformational change upon binding with $\mathrm{CaOx}$, demonstrate less potential binding toward $\mathrm{CaOx}$, and require water molecules for met binding. We have yet determined the primary sequence of $\mathrm{NC}$, and currently it is impossible to demonstrate an exact inhibition mechanism. However, a model can be hypothesized: A good inhibitor, isoform $\mathbf{A}$ or $\mathbf{B}$, changes its conformation upon binding $\mathrm{Ca}^{2+}$ and becomes ellipsoidal or rod-shaped with one side being hydrophobic and the other hydrophilic. The hydrophilic side of the inhibitor attaches at the crystal growth point of the $\mathrm{CaOx}$ crystal, and the hydrophobic side of the molecule faces outward which prevents further crystal growth. However, a poor inhibitor, isoform $\mathrm{C}$ or $\mathrm{D}$, does not change its conformation upon binding to $\mathrm{Ca}^{2+}$ atoms, thus the molecule remains bulky, possibly globular with hydrophylic and hydrophobic sites scattered over the surface of the molecule. Although this molecule attaches at the crystal growth point of $\mathrm{CaOx}$, it is not able to prevent crystal growth, since hydrophylic sites are on the surface of the molecule. Additional $\mathrm{CaOx}$ molecules can attach to the surface of the poor inhibitor causing crystal growth to continue.

Crystal growth inhibitors and promoters have been previously suggested; however, we propose that crystal growth inhibitors and promoters could essentially have the same origin. During evolutionary processes, genetic mutations resulted in the replacement of certain amino acid residues, producing a "good" inhibitor and a "poor" inhibitor which could in fact be a promoter.

$\mathrm{NC}$ is produced in proximal tubule cells, and it has been found that NC production increases with disease progression, and that the majority of patients return to normal NC levels after nephrectomy. This supports the idea that proximal tubule cells are responsible for production of NC molecules.

Acknowledgments: I thank Drs Coe FL. Makinen MW, Michaels EL, Mastafi $D$ and Otsuki $T$ for their useful discussions. This work was supported by National Institutes of Health (USA) Grant AM 33949, and O'Brien Kidncy Rescarch Center Grant 5-P50-DK47631.

\section{References}

1. Grover PK, Marshall VR, Ryall RL: The promotion of calcium oxalate crystallization by uratc: can it be that cpitaxy is not the cause after all? In: Ryall RL, ed, Urolithiasis 2, New York. Plenum Press, 1992; 201-203

2. Nancollas GH, Smesko SA, Campbell AA, Coyl-Recs $M$ Ebrahimpour A, Bincttc M, Bincttc JP: Mincralization inhibitors and promoters. In: Walker VR, ed, Urolithiasis, New York, Plcnum Press, 1989; 83-90

3. Scla J, Schwartz Z, Swain LD, Boyan BD: Role of matrix vesicles in calcification. In: Bonucci E, ed, Calcification in Biological Systems, Chapter 5, Boca Raton, CRC Press, 1992: 73-105

4. Linde A: Dentin matrix proteins: composition and possible functions in calcification. Anat Rec 1989; 224: 154-166

5. Addadi L, Weiner S: Interactions between acidic proteins and crystals: stereochemical requirements in biomincralization. Proc Natl Acad Sci USA 1985; 82: $4110-4114$ 
6. Iwata $H$, Kamei O, Abe $Y$, Nishio S, Wakatsuki A, Ochi K, Takeuchi M: The organic matrix of urinary uric acid crystals. J Urol 1988; 139: 607-610

7. Nakagawa Y, Ahmed M, Hall SL, Deganello S, Coe FL: Isolation from human calcium oxalate renal stones of nephrocalcin, a glycoprotein inhibitor of calcium oxalate crystal growth. Evidence that nephrocalcin from patients with calcium oxalate nephrolithiasis is deficient in gamma-carboxyglutamic acid. J Clin Invest 1987; 79: 1782-1787

8. Maxfield M: Urinary mucopolysaccharides. Ann Rev Med 1995; 14: $99-110$

9. Umekawa $T$, Kohri $K$, Amasaki N, Yamate $T$, Yoshida $K$, Yamamoto K, Suzuki Y, Sinohara H, Kurita T: Sequencing of a urinary stone protein, identical to alpha-one antitrypsin, which lacks 22 amino acids. Biochem Biophys Res Commun 1993; 193 : 1049-1053

10. Rodgers A: Nucleation and growth inhibitor of calcium oxalate crystallization. In: Walker VR, eds, Urolithiasis, New York, Plenum Press, 1989, 189-191

11. Doyle IR, Ryall RL, Marshall VR: Inclusion of proteins into calcium oxalate crystals precipitated from human urine: a highly selective phenomenon. Clin Chem 1991; 37: 1589-1594

12. Stapleton AM, Ryall RL: Blood coagulation proteins and urolithiasis are linked: crystal matrix protein is the $F_{1}$ activation peptide of human prothrombin. Br J Urol 1995; 75: 712-719

13. Ito $\mathbf{H}$, Coe FL: Acidic peptides and polyribonucleotides crystal growth inhibitors in human urine. Am J Physiol 1977; 233: F455F463

14. Morse RM, Resnick MI: A new approach to the study of urinary macromolecules as a participant in calcium oxalate crystallization.
J Urol 1988; 139: 869-873

15. Dussol B, Geider S, Lilova A, Leonetti F, Dupuy P, Daudon M, Berland Y, Dagorn JC, Verdier JM: Analysis of the soluble organic matrix of five morphologically different kidney stones. Evidence for a specific role of albumin in the constitution of the stone protein matrix. Urol Res 1995; 23: 45-51

16. Fraij BM: Separation and identification of urinary proteins and stone-matrix proteins by mini-slab sodium dodecyl sulfatepolyacrylamide gel electrophoresis. Clin Chem 1989; 35: 658-662

17. Shiraga H, Min W, VanDusen WJ, Clayman MD, Miner D, Terrell CH, Sherbotie JR, Foreman JW, Przysiecki C, Neilson EG, Hoyer JR: Inhibition of calcium oxalate crystal growth in vitro by uropontin: another member of the aspartic acid-rich protein superfamily. Proc Natv Acad Sci USA 1992; 89: 426-430

18. Nakagawa $Y$, Renz CL, Ahmed M, Coe FL: Isolation of nephrocalcin from kidney tissue of nine vertebrate species. Am J Physiol 1991; 260(Pt 2): F243-F248

19. Nakagawa $Y$, Otsuki T, Coe FL: Elucidation of multiple forms of nephrocalcin by ${ }^{31}$ P-NMR spectrometer. FEBS Lett 1989; 250: $187-190$

20. deKernion JB, Belldegrun A: Renal tumors. In: Walsh PC, Retik AB, Stamey TA, Vaughan ED Jr, eds, Campbell's Urology, 6th Ed, Vol 2, Chapter 27, Philadelphia, W. B. Saunders, 1992; 1053-1093

21. Mustafi D, Nakagawa Y: Characterization of calcium-binding sites in the kidney stone inhibitor glycoprotein nephrocalcin with vanadyl ions: electron paramagnetic resonance and electron nuclear double resonance spectroscopy. Proc Natl Acad Sci USA 1994; 91: $11323-11327$ 